\title{
Psychrophilic sulfate-reducing bacteria isolated from permanently cold Arctic marine sediments: description of Desulfofrigus oceanense gen. nov., sp. nov., Desulfofrigus fragile sp. nov., Desulfofaba gelida gen. nov., sp. nov., Desulfotalea psychrophila gen. nov., sp. nov. and Desulfotalea arctica sp. nov.
}

\author{
Christian Knoblauch, Kerstin Sahm and Bo B. Jørgensen
}

Author for correspondence: Christian Knoblauch. Tel: +49421 2028 653. Fax: + 494212028690.
e-mail: cknoblau@mpi-bremen.de

Max-Planck-Institute for Marine Microbiology, Celsiusstr. 1, 28359 Bremen, Germany
Five psychrophilic, Gram-negative, sulfate-reducing bacteria were isolated from marine sediments off the coast of Svalbard. All isolates grew at the in situ temperature of $-1.7^{\circ} \mathrm{C}$. In batch cultures, strain PSv29' had the highest growth rate at $7^{\circ} \mathrm{C}$, strains ASv26 ${ }^{\top}$ and LSv54 ${ }^{\top}$ had the highest growth rate at $10^{\circ} \mathrm{C}$, and strains $L S v 21^{\top}$ and LSv514 ${ }^{\top}$ had the highest growth rate at $18{ }^{\circ} \mathrm{C}$. The new isolates used the most common fermentation products in marine sediments, such as acetate, propionate, butyrate, lactate and hydrogen, but only strain ASv26 ${ }^{\top}$ was able to oxidize fatty acids completely to $\mathrm{CO}_{2}$. The new strains had growth optima at neutral $\mathrm{pH}$ and marine salt concentration, except for LSv54 ${ }^{\top}$ which grew fastest with $1 \% \mathrm{NaCl}$. Sulfite and thiosulfate were used as electron acceptors by strains ASv26 ${ }^{\top}, \mathrm{PSV}^{\top}{ }^{\top}$ and $\mathrm{LSv}^{\mathrm{N}}{ }^{\top}$, and all strains except PSV29' grew with $\mathrm{Fe}^{3+}$ (ferric citrate) as electron acceptor.

Chemotaxonomy based on cellular fatty acid patterns and menaquinones showed good agreement with the phylogeny based on 165 rRNA sequences. All strains belonged to the $\delta$ subclass of Proteobacteria but had at least $9 \%$ evolutionary distance from known sulfate reducers. Due to the phylogenetic and phenotypic differences between the new isolates and their closest relatives, establishment of the new genera Desulfotalea gen. nov., Desulfofaba gen. nov. and Desulfofrigus gen. nov. is proposed, with strain $A S v 26^{\top}$ as the type strain of the type species Desulfofrigus oceanense sp. nov., LSv21 ${ }^{\top}$ as the type strain of Desulfofrigus fragile sp. nov., PSv29' as the type strain of the type species Desulfofaba gelida sp. nov., LSv54' as the type strain of the type species Desulfotalea psychrophila sp. nov. and LSv514 ${ }^{\top}$ as the type strain of Desulfotalea arctica sp. nov.

Keywords: sulfate-reducing bacteria, psychrophiles, chemotaxonomy, Arctic sediment, Svalbard

\section{INTRODUCTION}

Sulfate reducers are responsible for up to $50 \%$ of the

Abbreviations: $\mathrm{ECL}$, equivalent chain-length; $\mathrm{MK}$, menaquinone.

The GenBank accession numbers for the 165 rDNA sequences of Desulfotalea arctica LSv514', Desulfotalea psychrophila LSv54 ${ }^{\top}$, Desulfofaba gelida PSv29', Desulfofrigus oceanense ASv26 ${ }^{\top}$ and Desulfofrigus fragile LSv $21^{\top}$ are AF099061-AF099065, respectively. organic carbon remineralization in marine sediments (Jørgensen, 1982; Canfield et al., 1993; Nedwell et al., 1993). Acetate, propionate, lactate, butyrate and hydrogen, which are the major end-products of fermentation, constitute their most important carbon and energy substrates (Sørensen et al., 1981; Christensen, 1984; Parkes et al., 1989). According to their nutrition, sulfate-reducing bacteria can be separated into two distinct groups. Lactate, hydrogen and propionate are 
the typical substrates for incompletely oxidizing sulfate-reducing bacteria, which are mainly represented by Desulfovibrio and Desulfobulbus species. The main end-product of their catabolism is acetate which they do not oxidize further. The major substrates of completely oxidizing sulfate-reducing bacteria like Desulfobacter, Desulfobacterium, Desulfococcus and Desulfosarcina strains, are fatty acids which are oxidized to $\mathrm{CO}_{2}$ (Holt et al., 1994). Phylogenetically, most sulfate reducers belong to the $\delta$ subclass of Proteobacteria.

The natural environment of most sulfate reducers is cold, since $90 \%$ of the sea floor has temperatures below $4{ }^{\circ} \mathrm{C}$ (Levitus \& Boyer, 1994). Like other benthic bacteria, sulfate reducers must therefore be able to grow at low temperatures. However, nearly all the known isolates are mesophiles with a temperature optimum at or above $30^{\circ} \mathrm{C}$ and unable to grow below $4{ }^{\circ} \mathrm{C}$ (Widdel \& Bak, 1992). It was unclear whether those sulfate reducers active at low in situ temperatures are closely related to the known mesophiles or whether they represent members of new genera and species. Pure cultures were needed to understand their metabolism and temperature adaptation as well as their phylogeny. The first moderately psychrophilic sulfatereducing species, Desulforhopalus vacuolatus, was isolated by Isaksen \& Teske (1996) from a temperate estuary. In polar environments with permanent temperatures around $0{ }^{\circ} \mathrm{C}$, low-temperature-adapted bacteria should be the dominant organisms. The aim of the present study was to isolate and describe the most abundant low-temperature-adapted sulfate reducers from polar sediments. Special attention was paid to organisms oxidizing acetate, propionate, lactate and butyrate.

\section{METHODS}

Sources of organisms. Arctic marine sediments at Svalbard were sampled in 1995 on a cruise with the RV 'Jan Mayen'. Strains LSv2 $1^{\mathrm{T}}, \mathrm{ASv} 26^{\mathrm{T}}$ and PSv29 $9^{\mathrm{T}}$ originated from Hornsund sediment $\left(76^{\circ} 58 \cdot 2^{\prime} \mathrm{N}, 15^{\circ} 34 \cdot 5^{\prime} \mathrm{E}\right)$ with a bottom water temperature of $2.6^{\circ} \mathrm{C}$. Strains LSv54 ${ }^{\mathrm{T}}$ and LSv $514^{\mathrm{T}}$ were isolated from Storfjord sediment $\left(77^{\circ} 33 \cdot 0^{\prime} \mathrm{N}\right.$, $\left.19^{\circ} 05 \cdot 0^{\prime} \mathrm{E}\right)$ with a bottom water temperature of $-1.7^{\circ} \mathrm{C}$. Further information about sampling sites are given in Glud et al. (1998). Desulforhopalus vacuolatus strain 1 tk $10^{\mathrm{T}}$ (= DSM $9700^{\mathrm{T}}$ ) was kindly provided by Kai Finster, Århus, Denmark; Desulfovibrio giganteus (DSM 4123) was obtained from the Deutsche Sammlung von Mikroorganismen und Zellkulturen (DSMZ), Braunschweig, Germany.

Enrichment, isolation and cultivation. Sediment samples were collected with a multicorer and subsampled directly on the deck of the ship at an ambient temperature of $2-7^{\circ} \mathrm{C}$. Subcores were sliced in an anaerobic glove bag and samples from five sediment depths between the surface and $30 \mathrm{~cm}$ were transferred to $90 \mathrm{ml}$ sterile artificial seawater medium. These samples were suspended for $2 \mathrm{~min}$ with a vortex mixer and further diluted in $15 \mathrm{ml}$ Hungate tubes containing $10 \mathrm{ml}$ medium (Widdel \& Bak, 1992). The medium contained $\left(\mathrm{g} \mathrm{l}^{-1}\right): \mathrm{NaCl}, 26 \cdot 4 ; \mathrm{MgSO}_{4} .7 \mathrm{H}_{2} \mathrm{O}, 6 \cdot 8 ; \mathrm{MgCl}_{2} .6 \mathrm{H}_{2} \mathrm{O}, 5 \cdot 7$; $\mathrm{CaCl}_{2} .2 \mathrm{H}_{2} \mathrm{O}, 1 \cdot 5 ; \mathrm{KBr}, 0.09$; and $\mathrm{KCl}, 0.7$. After autoclaving, the medium was cooled under a gas mixture of $\mathrm{CO}_{2} / \mathrm{N}_{2}(10 / 90, \mathrm{v} / \mathrm{v})$ and the following components were added: $50 \mathrm{ml}$ of a $\mathrm{NH}_{4} \mathrm{Cl}\left(5 \mathrm{~g} \mathrm{l}^{-1}\right)$ and $\mathrm{KH}_{2} \mathrm{PO}_{4}\left(4 \mathrm{~g} \mathrm{l}^{-1}\right)$ solution, $1 \mathrm{ml}$ nonchelated trace element solution, $1 \mathrm{ml}$ selenite/tungstate solution, $1 \mathrm{ml}$ vitamin solution (modified solution 6 , with an additional $4 \mathrm{mg}$ folic acid and $1.5 \mathrm{mg}$ lipoic acid per $100 \mathrm{ml}$ ), $1 \mathrm{ml}$ thiamin solution, $1 \mathrm{ml}$ vitamin $\mathrm{B}_{12}$ solution, $1 \mathrm{ml}$ riboflavin solution $\left(25 \mathrm{mg} \mathrm{l}^{-1}\right.$ in $25 \mathrm{mM}$ phosphate buffer, $\mathrm{pH} 3 \cdot 2$ ), $30 \mathrm{ml}$ bicarbonate solution (1 M), $1 \mathrm{ml}$ resazurin solution $\left(1 \mathrm{~g}^{-1}\right)$ and $1 \mathrm{ml}$ sodium sulfide solution $(1 \mathrm{M})$. If necessary, the $\mathrm{pH}$ was adjusted with $\mathrm{HCl}$ or $\mathrm{NaOH}$ to $7 \cdot 1-7 \cdot 3$. The medium was dispensed under an atmosphere of $\mathrm{CO}_{2} / \mathrm{N}_{2}(10 / 90, \mathrm{v} / \mathrm{v})$ into sterile serum bottles that were closed with black butyl rubber stoppers or into sterile $15 \mathrm{ml}$ Hungate tubes. Before inoculating the medium, dithionite (final concentration $150 \mu \mathrm{M}$ ) and the desired carbon source were added from sterile stock solutions. The dilution series were inoculated on board ship and transported back at $4{ }^{\circ} \mathrm{C}$. In our laboratory, they were incubated at five different temperatures between 0 and $20^{\circ} \mathrm{C}$. For the isolation of pure cultures, the modified deep agar dilution technique (Isaksen \& Teske, 1996) was applied, which protects temperature-sensitive organisms from overheating. Agar (Noble; DIFCO) was washed five times with distilled water (Widdel \& Bak, 1992) before use. After three to four subsequent agar dilution series, 30 different pure cultures were isolated from the 0,4 and $10^{\circ} \mathrm{C}$ enrichments. Stock cultures were kept at the temperature used for isolation and transferred every 3-4 weeks to fresh medium. For the characterization of pure cultures, the saltwater medium (Widdel \& Bak, 1992) with a lower concentration of major salts was used. This medium contained $\left(\mathrm{g} \mathrm{l}^{-1}\right): \mathrm{NaCl}, 20$; $\mathrm{Na}_{2} \mathrm{SO}_{4}, 4 ; \mathrm{MgCl}_{2} \cdot 6 \mathrm{H}_{2} \mathrm{O}, 3 ; \mathrm{CaCl}_{2} .2 \mathrm{H}_{2} \mathrm{O}, 0 \cdot 15 ; \mathrm{KBr}, 0.09$; and $\mathrm{KCl}, 0 \cdot 5$. After autoclaving, the medium was prepared as described above. To prevent damage of temperaturesensitive cells, great care was taken to protect enrichments and pure cultures from temperatures above those used for isolation.

Physiology and metabolism. The salt requirement for growth was monitored in media with 15 different $\mathrm{NaCl}$ concentrations between 0.2 and $5.8 \%(\mathrm{w} / \mathrm{v})$ or 16 different $\mathrm{MgCl}_{2} \cdot 6 \mathrm{H}_{2} \mathrm{O}$ concentrations between 0.0 and $7.0 \%(\mathrm{w} / \mathrm{v})$. The concentrations of all other salts, except the one being tested, were kept constant. The vitamin demand of the different strains was tested for at least ten subsequent transfers on medium without vitamins. The $\mathrm{pH}$ optimum was tested using media adjusted to 12 different $\mathrm{pH}$ values between 4.9 and $9 \cdot 1$. The $\mathrm{pH}$ was adjusted in triplicate tubes with $\mathrm{HCl}$ or $\mathrm{NaOH}$ and the tubes were inoculated. The initial $\mathrm{pH}$ was measured in one tube and the remaining tubes were incubated. Sulfide was measured periodically during the following six months. Growth with different electron donors was tested with sulfate as electron acceptor. Tubes without an electron donor were inoculated and served as negative controls. Sulfide was measured periodically during the following year. Growth tests on different electron acceptors were made in sulfate-free medium which was supplied with the carbon source used for isolation of the tested strain and either thiosulfate $(10 \mathrm{mM})$, elemental sulfur, nitrate $(5 \mathrm{mM})$, nitrite $(2 \mathrm{mM})$, iron(III) oxyhydroxide or iron(III) citrate (30 mM). Amorphous iron(III) oxyhydroxide was prepared by titration of an acidic $\mathrm{FeCl}_{3}$ solution $(0.5 \mathrm{M})$ with $\mathrm{NaOH}(2 \mathrm{M})$ to $\mathrm{pH} 7 \cdot 0$. Elemental 
sulfur was added with a spatula from a sterilized suspension; all other electron acceptors were added from sterilized stock solutions. Tubes without an electron donor served as negative controls. Disproportionation of thiosulfate and elemental sulfur was tested in sulfate-free medium. Either $20 \mathrm{mM}$ thiosulfate or elemental sulfur plus iron(III) oxyhydroxide was added to the tubes. Additionally $2 \mathrm{mM}$ acetate was added as a carbon source. All test-tubes were inoculated with a sulfate-free preculture. The same precultures were used as inocula for fermentation tests. Test tubes contained no electron acceptor but did contain lactate, pyruvate, fumarate, malate or propionate at a final concentration of $10 \mathrm{mM}$. Growth was measured by direct counts under the light microscope. All tests were incubated at least in duplicate at the temperature used for isolation of the different strains, i.e. 4 or $10^{\circ} \mathrm{C}$.

Fatty acids, lipoquinones and polar lipids. Cellular fatty acids were determined at the DSMZ, Braunschweig, Germany by R. M. Kroppenstedt. Fatty acid methyl esters were obtained by saponification and separated by GC as described by Vainshtein et al. (1992). Respiratory lipoquinones and polar lipids were extracted from freeze-dried cell material and analysed by TLC (Tindall, 1990). The analyses were carried out by B. J. Tindall at the DSMZ.

Pigments and Gram-staining. The desulfoviridin test was carried out as described by Postgate (1984). Desulfovibrio giganteus (DSM 4123) served as positive control. To determine the Gram-reaction of the strains, heat-fixed cells were stained with Crystal Violet as described by Murray et al. (1994).

$\mathbf{G}+\mathbf{C}$ content of genomic DNA. The $\mathrm{G}+\mathrm{C}$ content of the genomic DNA was determined by HPLC (Mesbah et al., 1989) at the DSMZ.

Chemical analysis. Sulfide was measured according to the quick method described by Cord-Ruwisch (1985). If higher precision was needed, the methylene blue method of Cline (1969) was applied. Volatile fatty acids and lactate were determined by ion-exclusion chromatography with an HPLC system (Sykam) and a refractometer (ERC-7515) as detector. The components were separated on a Sarasep WA1 column $(300 \times 7.8 \mathrm{~mm})$ at $60{ }^{\circ} \mathrm{C}$ with $\mathrm{H}_{2} \mathrm{SO}_{4}(15 \mathrm{mM})$ as eluent. The flow was adjusted to $0.6 \mathrm{ml} \mathrm{min}{ }^{-1}$. Fifty microlitres of a $0.45-\mu \mathrm{m}$-filtered sample (Acrodisc 4; Gelman Sciences) was injected onto the column. Dissolved $\mathrm{Fe}^{2+}$ was determined according to Stookey (1970) with a Ferrozine solution $\left(1 \mathrm{~g} \mathrm{l}^{-1}\right.$ in $50 \mathrm{mM}$ HEPES buffer, $\left.\mathrm{pH} 7 \cdot 0\right)$. A $100 \mu \mathrm{l}$ sample was diluted in $5 \mathrm{ml} \mathrm{HCl}(0.5 \mathrm{M})$ and after $15 \mathrm{~min}$, $50 \mu \mathrm{l}$ were removed and added to $2.5 \mathrm{ml}$ Ferrozine solution and measured in a spectrophotometer (UV-1202; Shimadzu) at a wavelength of $562 \mathrm{~nm}$. Organic carbon was determined in a CHNS analyser (Cutter \& Radford-Knoery, 1991). A known culture volume was filtered on two GF/F-filters $(1.28 \mathrm{~cm}$; Frisenette) placed in two filter holders on top of each other. The lower filter was used as a blank. The filters were flushed with a marine salt solution and then dried in a stream of sterile-filtered air. The filters were placed in tin capsules and $50 \mu \mathrm{l}$ distilled water and $50 \mu \mathrm{l} \mathrm{HCl}(50 \mathrm{mM})$ were added to dissolve the bicarbonate. After $2 \mathrm{~h}$, the filters were dried overnight at $105^{\circ} \mathrm{C}$ and analysed on a CHNS analyser (Fisons).

Growth determination and growth rates. Since most of the isolates tended to grow in aggregates, the determination of growth via an increase in the OD was difficult. Growth was therefore measured routinely by the increase of sulfide in the cultures. Sulfide concentrations correlated significantly with bacterial cell numbers in the cultures $(P<0.005)$. If direct cell counts or OD were needed, cultures were carefully homogenized with an ultrasonic probe (HD200; Bandelin) applying the lowest intensity. Microscopic controls revealed that cells were not damaged by this treatment. Direct cell counts were made under the microscope in an improved Neubauer chamber. The OD was measured in a spectrophotometer (UV-1202) at $580 \mathrm{~nm}$. Growth rates were calculated in exponentially growing cultures by a linear regression of $\ln \left(\mathrm{OD}_{580}\right)$ as a function of time.

DNA isolation and DNA-DNA hybridization. DNA of strains LSv514 ${ }^{\mathrm{T}}, \mathrm{LSv} 54^{\mathrm{T}}$ and Desulforhopalus vacuolatus $1 \mathrm{tk} 10^{\mathrm{T}}$ was isolated according to Marmur (1961). DNA-DNA hybridization was performed using the hydroxyapatite method as described by Ziemke et al. (1998) except that DNA was labelled with $\left[{ }^{32} \mathrm{P}\right] \mathrm{dCTP}$ by nick-translation as described by Rosselló-Mora et al. (1994). After denaturation, DNA-DNA mixtures were incubated at $30^{\circ} \mathrm{C}$ below the melting temperature of homologous DNA, which in our case was $62^{\circ} \mathrm{C}$ for all hybridization pairs. The degree of reassociation (binding ratio) was calculated by dividing the counts for double-stranded DNA by the total counts for double- and single-stranded DNA. The relative binding ratio for the heterologous pairs is expressed as the percentage of homologous binding (Lind \& Ursing, 1986).

16S rDNA amplification. Cells were harvested from $2 \mathrm{ml}$ culture samples by centrifugation and resuspended in $100 \mu l$ $1 \times$ PBS. A subsample of $1 \mu l$ was used directly as a template for the amplification of $16 \mathrm{~S}$ rDNA. PCR reactions were performed as described by Buchholz-Cleven et al. (1997). To amplify the nearly complete $16 \mathrm{~S}$ rDNA, primers $8 \mathrm{~F} / 1492 \mathrm{R}$ (Buchholz-Cleven et al., 1997) were used in a 35 cycle PCR with an annealing temperature of $40^{\circ} \mathrm{C}$.

165 rDNA sequencing. PCR products were purified with the QIAquick PCR Purification kit (Qiagen). The Taq DyeDeoxy Terminator Cycle Sequencing kit (Applied Biosystems) was used to directly sequence the purified PCR products. Sequencing reactions were analysed on the Applied Biosystems 373S DNA sequencer. Both strands of the amplification products were sequenced using primers $8 \mathrm{~F}$, 787F, 787R, 1175R, 1099F and 1492R (Buchholz-Cleven et al., 1997). Primer nomenclature refers to the $5^{\prime}$ ends of the respective target sites on the 16S rDNA according to the Escherichia coli numbering of 16S rRNA nucleotides (Brosius et al., 1981).

Phylogenetic analysis. The ARB program package and the ARB database (Strunk et al., 1999) were used for phylogenetic analysis. Sequences were aligned to the 16S rRNA primary structures present in the ARB database by using the automatic aligning tool and the results were corrected manually where necessary. Pairwise distance matrix analysis was performed with the 16S rRNA sequences taking only those positions into account that were present in both sequences. Evolutionary distances were calculated using the Jukes-Cantor correction. Phylogenetic trees were reconstructed with representatives of most genera from the $\delta$ subclass of Proteobacteria. A selection of representatives for major groups outside this subclass was used as an outgroup. Only sequences with at least $1400 \mathrm{nt}$ were used. Tree topology was evaluated by using neighbour-joining, maximum-parsimony and maximum-likelihood algorithms on either the full set of data or on a selected subset. Furthermore, filters were applied that excluded positions with less than $50 \%$ conservation within the $\delta$ subclass. Branching orders that were not supported by all methods are shown as multifurcations. 
Naming of strains. The isolated strains were named with a code indicating the carbon source used for isolation ( $\mathrm{L}$, lactate; $A$, acetate; $\mathrm{P}$, propionate), the sampling site (Sv2, Hornsund; Sv5, Storfjord) and a number.

\section{RESULTS}

\section{Enrichment and isolation}

Enrichment cultures at 4 and $10{ }^{\circ} \mathrm{C}$ started to produce sulfide after 4 weeks if lactate was used as carbon source, and after $8-10$ weeks if acetate or propionate was used. Sulfide-producing enrichments were transferred to fresh medium until stable enrichments were obtained and then agar dilution series were inoculated. After 6-8 weeks, all dilution series were dominated by brownish to blackish, disk-shaped, smooth colonies. If lactate was used as carbon source, white, fluffy colonies were also present in the lower dilutions. Single colonies were picked and directly transferred to new dilution series until pure cultures were obtained. Only the brownish colonies contained sulfate reducers. Thirty pure cultures were isolated from different sediment samples and dilution steps. Based on a preliminary physiological and phylogenetic characterization, the five psychrophilic strains presented here were selected for further description. Strains LSv $21^{\mathrm{T}}, \mathrm{LSv} 54^{\mathrm{T}}$ and LSv $514^{\mathrm{T}}$ were isolated on lactate, whereas acetate was used for the isolation of $\mathrm{ASv} 26^{\mathrm{T}}$ and propionate was used for the isolation of PSv29 ${ }^{\mathrm{T}}$. The temperature during isolation was $4^{\circ} \mathrm{C}$ for ASv26 ${ }^{\mathrm{T}}, \mathrm{LSv} 21^{\mathrm{T}}, \mathrm{PSv} 29^{\mathrm{T}}$ and LSv $514^{\mathrm{T}}$ and $10^{\circ} \mathrm{C}$ for strain LSv54 $4^{\mathrm{T}}$.

\section{Purity controls}

All strains were transferred on media containing yeast extract $(0.1 \%, \mathrm{w} / \mathrm{v})$ and either formate $(20 \mathrm{mM})$, pyruvate $(10 \mathrm{mM})$, glucose $(5 \mathrm{mM})$, fructose $(5 \mathrm{mM})$ or the carbon source used for isolation of the respective strain. Microscopic examinations revealed that no morphologies different from those of the tested strains could be detected in any culture. Growth on yeast extract, glucose or fructose was never observed. The different strains were also transferred to agar dilution series. Only the strain-typical colony morphologies developed in all dilution steps.

\section{Morphology}

Cells of the acetate-oxidizing strain ASv26 ${ }^{\mathrm{T}}$ (Fig. 1a) were thick rods with rounded ends. Growth in loose clumps was often observed. Cells of strain LSv2 $1^{\mathrm{T}}$ (Fig. 1b) were slightly curved rods with rounded ends. PSv29T (Fig. 1c) was a large, slightly curved, peanutshaped rod. The cells grew exclusively in dense aggregates and single cells could rarely be observed at any growth stage. Cells of strain LSv54 ${ }^{\mathrm{T}}$ (Fig. 1d) often appeared in pairs. In exponentially growing cultures, one or two shorter cells between two long cells frequently could be observed. Cells of LSv514 (Fig. 1e) were short rods often growing in clumps containing up to several hundred cells. In old cultures of strains ASv26 $6^{\mathrm{T}}, \mathrm{LSv} 21^{\mathrm{T}}, \mathrm{PSv} 29^{\mathrm{T}}$ and LSv $54^{\mathrm{T}}$, some cells were motile. All isolated strains stained Gramnegative.

\section{Growth conditions}

All strains had $\mathrm{pH}$ optima in the neutral range (Table 1). Marine sodium concentrations supported optimum growth of ASv26 $6^{\mathrm{T}}$, LSv2 $1^{\mathrm{T}}$, PSv29 $9^{\mathrm{T}}$ and LSv $514^{\mathrm{T}}$ but the lower range of optimal sodium concentrations differed slightly (Table 1). Although strain LSv54 ${ }^{\mathrm{T}}$ was enriched and isolated on medium with a marine salt concentration of $2 \cdot 5 \% \mathrm{NaCl}$ and $1 \cdot 1 \% \mathrm{MgCl}_{2} \cdot 6 \mathrm{H}_{2} \mathrm{O}$, it had a remarkably lower salt optimum of $1 \% \mathrm{NaCl}$ and $0 \cdot 034-0 \cdot 700 \% \mathrm{MgCl}_{2} \cdot 6 \mathrm{H}_{2} \mathrm{O}$. Marine magnesium concentrations supported optimum growth of strains ASv $26^{\mathrm{T}}, \mathrm{LSv} 21^{\mathrm{T}}, \operatorname{PSv} 29^{\mathrm{T}}$ and LSv514 ${ }^{\mathrm{T}}$. All strains grew well at a temperature of $-1.8^{\circ} \mathrm{C}$, but optimum growth temperatures were up to $20^{\circ} \mathrm{C}$ higher (Table 1). LSv21 ${ }^{\mathrm{T}}$ and LSv $514^{\mathrm{T}}$ had highest growth rates $(\mu)$ at about $18^{\circ} \mathrm{C}$ with values of 0.036 and $0.021 \mathrm{~h}^{-1}$, respectively $\left(t_{\mathrm{d}}=19\right.$ and $33 \mathrm{~h}$, respectively), when grown on lactate. A lower optimum temperature of $10^{\circ} \mathrm{C}$ was characteristic for strains ASv26 $6^{\mathrm{T}}(\mu=$ $0.0041 \mathrm{~h}^{-1} ; t_{\mathrm{d}}=169 \mathrm{~h}$ on acetate $)$ and $\operatorname{LSv}^{\mathrm{T}} 4^{\mathrm{T}}(\mu=$ $0.026 \mathrm{~h}^{-1} ; t_{\mathrm{d}}=27 \mathrm{~h}$ on lactate). PSv $29^{\mathrm{T}}$ grew fastest at $7^{\circ} \mathrm{C}$ with $\mu$ of $0.0048 \mathrm{~h}^{-1}\left(t_{\mathrm{d}}=144 \mathrm{~h}\right.$ on propionate). At the next highest temperature tested $\left(10^{\circ} \mathrm{C}\right)$, this isolate could only reduce sulfate but not grow. A detailed description of the temperature response of the strains will be presented elsewhere (Knoblauch \& Jørgensen, 1999). Added vitamins were not required by any of the strains. Cultures were transferred usually with $10 \%$ inoculum since some of the strains exhibited a very long and unpredictable lag phase if smaller inocula were used. Strain LSv $21^{\mathrm{T}}$ lysed rapidly in the stationary phase and was therefore transferred every second week.

\section{Substrate spectra}

Strain ASv26 ${ }^{\mathrm{T}}$ grew on a wide variety of carbon sources (Table 1) and oxidized fatty acids such as formate, acetate, butyrate and valerate completely to $\mathrm{CO}_{2}$. Although LSv21 ${ }^{\mathrm{T}}$ was isolated on lactate, it also grew on longer-chain saturated fatty acids (C6, C10, C16) which were only incompletely oxidized to acetate. Fast growth was also found with different alcohols. PSv29 ${ }^{\mathrm{T}}$ was the only strain, that could grow on propionate, which was incompletely oxidized to acetate. Growth was also possible on alcohols and dicarboxylic acids. The substrate spectra of strains LSv $514^{\mathrm{T}}$ and $\mathrm{LSv} 54^{\mathrm{T}}$ were similar but distinct from those of strains LSv2 $1^{\mathrm{T}}$, ASv26 $6^{\mathrm{T}}$ and PSv $29^{\mathrm{T}}$ (Table 1). With the exception of formate, no straight-chain fatty acids were oxidized but both strains grew fast on hydrogen when acetate was added as carbon source. Lactate was incompletely oxidized to acetate. In comparison to LSv514 ${ }^{\mathrm{T}}$, strain LSv $54^{\mathrm{T}}$ had a wider substrate spectrum, also growing on various alcohols and amino acids. 

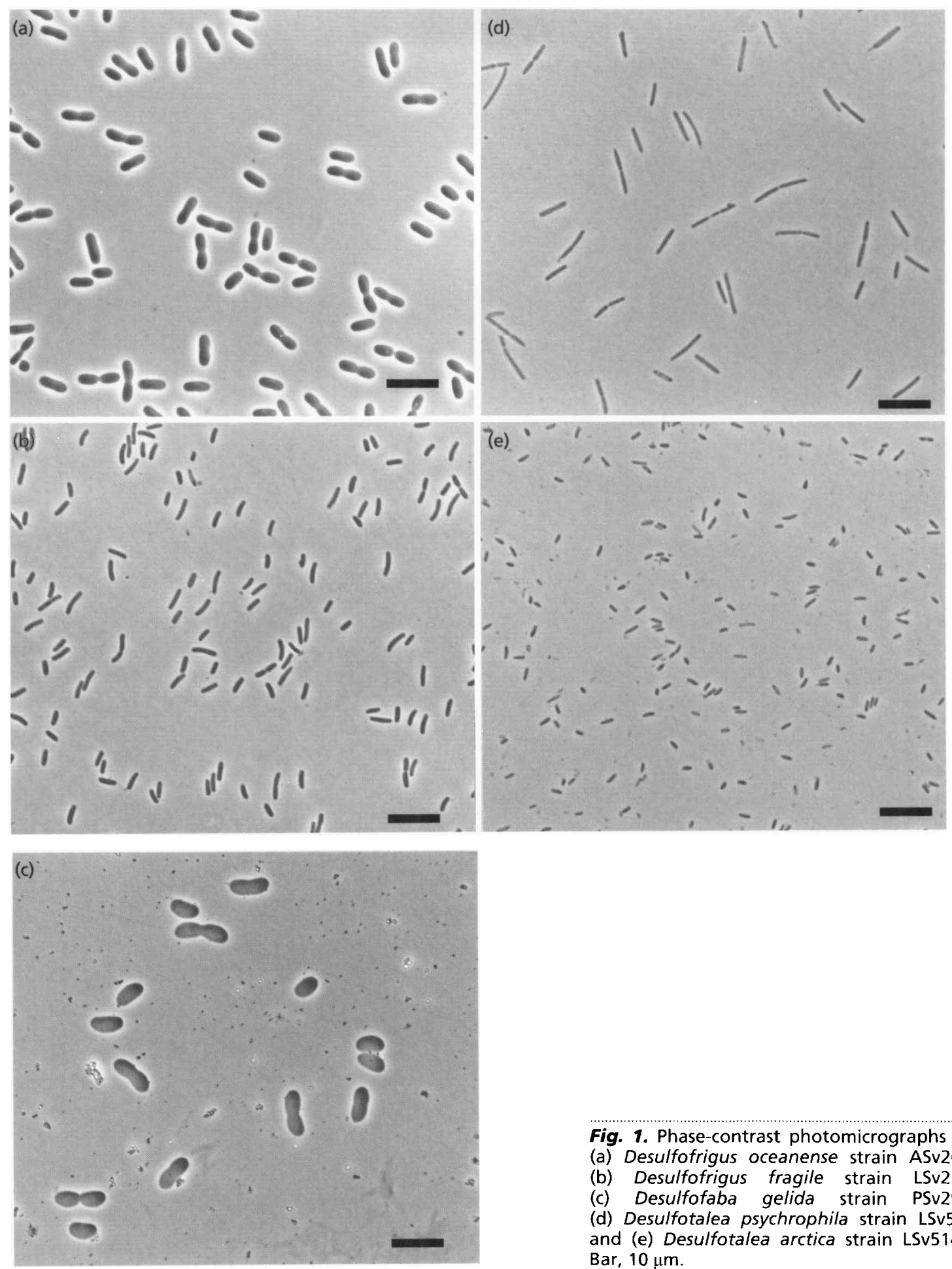

Fig. 1. Phase-contrast photomicrographs of (a) Desulfofrigus oceanense strain ASv2 $6^{\top}$

(b) Desulfofrigus fragile strain LSV $21^{\top}$.

(c) Desulfofaba gelida strain PSv29',

(d) Desulfotalea psychrophila strain $\mathrm{LSv} 54^{\top}$ and (e) Desulfotalea arctica strain LSv514 ${ }^{\top}$. Bar, $10 \mu \mathrm{m}$

The electron acceptors used by the different strains are listed in Table 1. Besides sulfate, strains ASv26 $6^{\mathrm{T}}$, PSv $29^{T}$ and LSv $54^{T}$ also used thiosulfate and sulfite as electron acceptors. ASv26 ${ }^{\mathrm{T}}, \mathrm{LSv} 21^{\mathrm{T}}, \mathrm{LSv} 54^{\mathrm{T}}$ and LSv $514^{\mathrm{T}}$ grew with iron(III), added as ferric citrate, as an electron acceptor. LSv514 ${ }^{\mathrm{T}}$ also reduced iron(III) oxyhydroxide and sulfur very slowly but could not grow on these electron acceptors. All isolated strains fermented pyruvate but none disproportionated thiosulfate or elemental sulfur.

\section{Pigments, polar lipids and respiratory quinones}

Desulfoviridin was not detected in any of the strains. The major polar lipids of all strains were phosphatidylethanolamine and phosphatidylglycerol (Table 1); in 
Table 1. Some characteristics of new psychrophilic sulfate-reducing bacteria

\begin{tabular}{|c|c|c|c|c|c|}
\hline Characteristic & $\begin{array}{l}\text { Desulfofrigus } \\
\text { oceanense } \\
\text { ASv26 }^{\mathrm{T}}\end{array}$ & $\begin{array}{l}\text { Desulfofrigus } \\
\quad \text { fragile } \\
\text { LSv21 }^{\mathrm{T}}\end{array}$ & $\begin{array}{l}\text { Desulfofaba } \\
\text { gelida } \\
\text { PSv29 }^{\mathrm{T}}\end{array}$ & $\begin{array}{l}\text { Desulfotalea } \\
\text { psychrophila } \\
\text { LSv54 }^{\mathrm{T}}\end{array}$ & $\begin{array}{l}\text { Desulfotalea } \\
\text { arctica }^{\mathrm{T}} \\
\text { LSv514 }^{\mathrm{T}}\end{array}$ \\
\hline Cell size $(\mu \mathrm{m})$ : & & & & & - \\
\hline Width & $2 \cdot 1$ & $0 \cdot 8$ & $3 \cdot 1$ & 0.6 & $0 \cdot 7$ \\
\hline Length & $4 \cdot 2-6 \cdot 1$ & $3 \cdot 2-4 \cdot 2$ & $5 \cdot 4-6 \cdot 2$ & $4 \cdot 5-7 \cdot 4$ & $1 \cdot 6-2 \cdot 7$ \\
\hline pH optimum & $7 \cdot 0-7 \cdot 5$ & $7 \cdot 0-7 \cdot 4$ & $7 \cdot 1-7 \cdot 6$ & $7 \cdot 3-7 \cdot 6$ & $7 \cdot 2-7 \cdot 9$ \\
\hline \multicolumn{6}{|l|}{$\begin{array}{l}\text { Optimum salt requirement } \\
(\%):\end{array}$} \\
\hline $\mathrm{NaCl}$ & $1 \cdot 5-2 \cdot 5$ & $1 \cdot 0-2 \cdot 5$ & $1.4-2.5$ & $1 \cdot 0$ & $1.9-2.5$ \\
\hline $\mathrm{MgCl}_{2} \cdot 6 \mathrm{H}_{2} \mathrm{O}$ & $0 \cdot 003-2 \cdot 0$ & $0 \cdot 3-2 \cdot 0$ & $0.015-2 \cdot 5$ & $0.03-0 \cdot 7$ & $0 \cdot 3-1 \cdot 4$ \\
\hline $\begin{array}{l}\text { Temperature } \\
\text { optimum/range }\left({ }^{\circ} \mathrm{C}\right)\end{array}$ & $10 /-1 \cdot 8-16$ & $18 /-1 \cdot 8-27$ & $7 /-1 \cdot 8-10$ & $10 /-1 \cdot 8-19$ & $18 /-1 \cdot 8-26$ \\
\hline $\begin{array}{l}\text { Growth rate }\left(\mathrm{h}^{-1}\right) / \text { doubling } \\
\text { time }(\mathrm{h}) \text { at optimum } \\
\text { temperature }\end{array}$ & $0.0041 / 169$ & $0.036 / 19$ & $0.0048 / 144$ & $0 \cdot 026 / 27$ & $0 \cdot 021 / 33$ \\
\hline \multicolumn{6}{|l|}{ Electron donors $(\mathrm{mM}):^{*}$} \\
\hline Formate (20) & ++ & + & + & ++ & ++ \\
\hline Acetate $(10)$ & ++ & - & - & - & - \\
\hline Propionate (15) & - & - & ++ & - & - \\
\hline Butyrate (5) & ++ & + & + & - & - \\
\hline Valerate (5) & + & - & - & - & - \\
\hline Caproate (3) & - & ++ & - & - & - \\
\hline Caprate (2) & - & ++ & - & - & - \\
\hline Palmitate (2) & - & +- & - & - & - \\
\hline Lactate (10) & ++ & ++ & ++ & ++ & ++ \\
\hline Pyruvate (10) & + & ++ & + & $++\dagger$ & ++ \\
\hline Malate (10) & ++ & ++ & + & +- & - \\
\hline Succinate (10) & - & - & + & - & - \\
\hline Fumarate (10) & - & + & + & ++ & - \\
\hline Ethanol (10) & ++ & ++ & ++ & ++ & ++ \\
\hline Propanol (10) & ++ & ++ & ++ & ++ & - \\
\hline Butanol (10) & ++ & ++ & ++ & $i+$ & - \\
\hline Glycerol (10) & +- & ++ & +- & - & + \\
\hline Glycine (10) & +- & - & +- & + & - \\
\hline Alanine (10) & - & + & + & + & - \\
\hline Serine $(10)$ & +- & + & - & + & +- \\
\hline $\mathrm{H}_{2} / \mathrm{CO}_{2}+$ acetate $(2)$ & +- & - & - & ++ & ++ \\
\hline \multicolumn{6}{|l|}{ Electron acceptors $(\mathrm{mM}): \ddagger$} \\
\hline Sulfate (28) & + & + & + & + & + \\
\hline Thiosulfate (10) & + & - & + & + & - \\
\hline Sulfite (2) & + & - & + & + & - \\
\hline Sulfur & - & - & - & - & $-\S$ \\
\hline Iron(III) citrate (30) & + & + & - & + & + \\
\hline Iron(III) oxyhydroxide & - & - & - & - & $-\|$ \\
\hline \multicolumn{6}{|l|}{$\begin{array}{l}\text { Fermentable compounds } \\
(\mathrm{mM}) \text { : }\end{array}$} \\
\hline Pyruvate (10) & + & + & + & + & + \\
\hline Malate (10) & + & + & - & - & - \\
\hline Lactate (10) & + & - & - & - & - \\
\hline Fumarate (10) & - & - & + & + & - \\
\hline Polar lipids & PE, PG & PE, PG & PE, PG & $\begin{array}{l}\text { PE, PG, } \\
\text { DPG }\end{array}$ & $\begin{array}{l}\text { PE, PG, } \\
\text { DPG }\end{array}$ \\
\hline Major menaquinones & MK-9 & MK-9 & MK-8 & $\mathrm{MK}-6 \mathrm{H}_{2}$ & MK-6 \\
\hline $\mathrm{G}+\mathrm{C}$ content $(\mathrm{mol} \%)$ & $52 \cdot 8$ & $52 \cdot 1$ & $52 \cdot 5$ & $46 \cdot 8$ & $41 \cdot 8$ \\
\hline
\end{tabular}

* Sulfate $(28 \mathrm{mM})$ was used as electron acceptor. Substrates tested $(\mathrm{mM})$ but not oxidized by any strains: formate (autotrophic), isovalerate (5), methanol (10), glutarate (10), betaine (10), choline chloride (10), L-proline (10), D-sorbitol (5), D-mannitol (5), benzoate 
Table 2. Fatty acid composition of psychrophilic sulfate-reducing bacteria

Abbreviations exemplified by: 14:0, tetradecanoic acid; 14:1c9, 9-tetradecenoic acid, double bond cis-standing; 15:0 3-OH, 3hydroxy-heptadecanoic acid; 16:0 alde, hexadecanal. Major fatty acids are printed in bold.

\begin{tabular}{|c|c|c|c|c|c|c|}
\hline Fatty acid & $\begin{array}{l}\text { Desulfofrigus } \\
\text { oceanense } \\
\text { ASv26 }^{\mathrm{T}}\end{array}$ & $\begin{array}{l}\text { Desulfofrigus } \\
\quad \text { fragile } \\
\text { LSv21 }^{\mathrm{T}}\end{array}$ & $\begin{array}{l}\text { Desulfofaba } \\
\text { gelida } \\
\text { PSv29 }^{\mathrm{T}}\end{array}$ & $\begin{array}{c}\text { Desulfotalea } \\
\text { psychrophila }^{\text {LSv54 }}\end{array}$ & $\begin{array}{c}\text { Desulfotalea } \\
\text { arctica } \\
\text { LSv514 }^{\mathrm{T}}\end{array}$ & $\begin{array}{c}\text { Desulforhapalus } \\
\text { vacuolatus } \\
\text { Itk } 10^{\mathrm{T}}\end{array}$ \\
\hline $10: 0$ & - & $2 \cdot 5$ & - & - & - & - \\
\hline $12: 0$ & - & $0 \cdot 6$ & - & - & - & - \\
\hline $13: 0$ & - & - & $2 \cdot 0$ & - & - & - \\
\hline $14: 0$ & 6.7 & $5 \cdot 0$ & 4.9 & 1.4 & - & - \\
\hline $14: 1 c 9$ & 0.9 & - & 0.5 & $1 \cdot 1$ & $1 \cdot 5$ & - \\
\hline $15: 0$ & - & - & $38 \cdot 1$ & 0.4 & - & $7 \cdot 7$ \\
\hline $15: 03-\mathrm{OH}$ & - & - & $0 \cdot 3$ & - & - & $2 \cdot 7$ \\
\hline $15: 1 c 9$ & - & - & $24 \cdot 7$ & 1.7 & - & 11.7 \\
\hline $16: 0$ alde & - & - & - & - & - & $2 \cdot 3$ \\
\hline $16: 0$ & $9 \cdot 3$ & $21 \cdot 7$ & $5 \cdot 4$ & 6.5 & $8 \cdot 3$ & $1 \cdot 7$ \\
\hline $16: 03-\mathrm{OH}$ & - & - & - & - & - & 0.6 \\
\hline $16: 1 c 7$ & $0 \cdot 7$ & $3 \cdot 0$ & $0 \cdot 5$ & 1.5 & $3 \cdot 6$ & - \\
\hline $16: 1 c^{9}$ & $43 \cdot 7$ & $30 \cdot 6$ & 6.5 & $55 \cdot 0$ & 53.9 & $2 \cdot 9$ \\
\hline $16: 1 c 11$ & $2 \cdot 2$ & 0.5 & 1.5 & 25.5 & 29.4 & $6 \cdot 3$ \\
\hline $17: 0$ & - & - & $1 \cdot 7$ & - & - & - \\
\hline $17: 1 c 11$ & - & - & $4 \cdot 4$ & $2 \cdot 4$ & - & 60.4 \\
\hline $18: 0$ & 0.6 & 0.7 & $0 \cdot 3$ & - & - & $0 \cdot 3$ \\
\hline $18: 03-\mathrm{OH}$ & - & - & $0 \cdot 3$ & - & - & - \\
\hline 18:0 alde & - & - & - & - & - & $1 \cdot 6$ \\
\hline $18: 1 c 9$ & $2 \cdot 8$ & 8.6 & - & - & - & - \\
\hline $18: 1 c 11$ & 23.0 & $18 \cdot 5$ & - & 1.5 & 1.5 & - \\
\hline $18: 1 c 13$ & $0 \cdot 4$ & - & - & 0.7 & $1 \cdot 0$ & - \\
\hline $20: 1 c 13$ & - & $0 \cdot 3$ & - & - & - & - \\
\hline
\end{tabular}

strains LSv54 ${ }^{\mathrm{T}}$ and LSv514 ${ }^{\mathrm{T}}$, diphosphatidylglycerol also was present in lower amounts. As indicated in Table 1, all strains contained menaquinones (MK). In strains ASv $26^{\mathrm{T}}$ and LSv $21^{\mathrm{T}}$, only MK-9 was present, which is uncommon for sulfate-reducing bacteria and has only been found in Desulfonema magnum (Collins \& Widdel, 1986). PSv2 $9^{\mathrm{T}}$ contained MK -8 as the sole menaquinone, which is also rare in sulfate-reducing bacteria but is characteristic for sulfur-reducing Desulfuromonas strains (Collins \& Widdel, 1986). In LSv $54^{\mathrm{T}}$, the major menaquinone was $\mathrm{MK}-6 \mathrm{H}_{2}$ but traces $(\approx 1 \%)$ of $\mathrm{MK}-5 \mathrm{H}_{2}$ also were present. LSv $514^{\mathrm{T}}$ only contained MK-6.

\section{Cellular fatty acids}

The cellular fatty acids of the different strains are presented in Table 2. The new isolates contained none of the fatty acids that are characteristic for known sulfate-reducing bacteria, namely the branched fatty acids for Desulfovibrio species (Vainshtein et al., 1992), the 16:0 10-me for Desulfobacter species (Dowling et al., 1986), or the 17:1c9 for Desulfobulbus species (Taylor \& Parkes, 1983). The two strains ASv26 ${ }^{\mathrm{T}}$ and LSv $21^{\mathrm{T}}$ had a similar fatty acid pattern dominated by $16: 1 c 9,18: 1 c 11$ and $16: 0$. Only even-numbered fatty acids were present, an indication of the use of acetyl$\mathrm{CoA}$ as precursor for chain elongation during the synthesis of fatty acids (Taylor \& Parkes, 1983). Both strains contained a fatty acid $(4.0$ and $5.6 \%$, respectively) with an equivalent chain-length (ECL) of 15.49 that could not be identified. A completely different pattern was found in strain PSv $29^{\mathrm{T}}$ which was dominated by the 15:0 fatty acids. This acid was also found $(23 \%)$ in Desulfobulbus species grown on propionate (Taylor \& Parkes, 1983), which was also

(1), nicotinate (1), $\mathrm{H}_{2}$ (autotrophic), glucose (5), fructose (5). ++ , Substrate oxidized after 6 weeks; + , substrate oxidized after 4 months; +-, substrate oxidized after 8 months or more; - , substrate not oxidized.

$\dagger$ No sulfide produced, only fermentative growth.

$\$$ Nitrate and nitrite were not reduced by any of the strains.

$\S$ Reduction of elemental sulfur up to a concentration of $3 \mathrm{mM}$ but no growth.

II $4 \mathrm{mM}$ iron(III) reduced after 1 year.

9 PE, Phosphatidylethanolamine; PG, phosphatidylglycerol; DPG, diphosphatidylglycerol. 


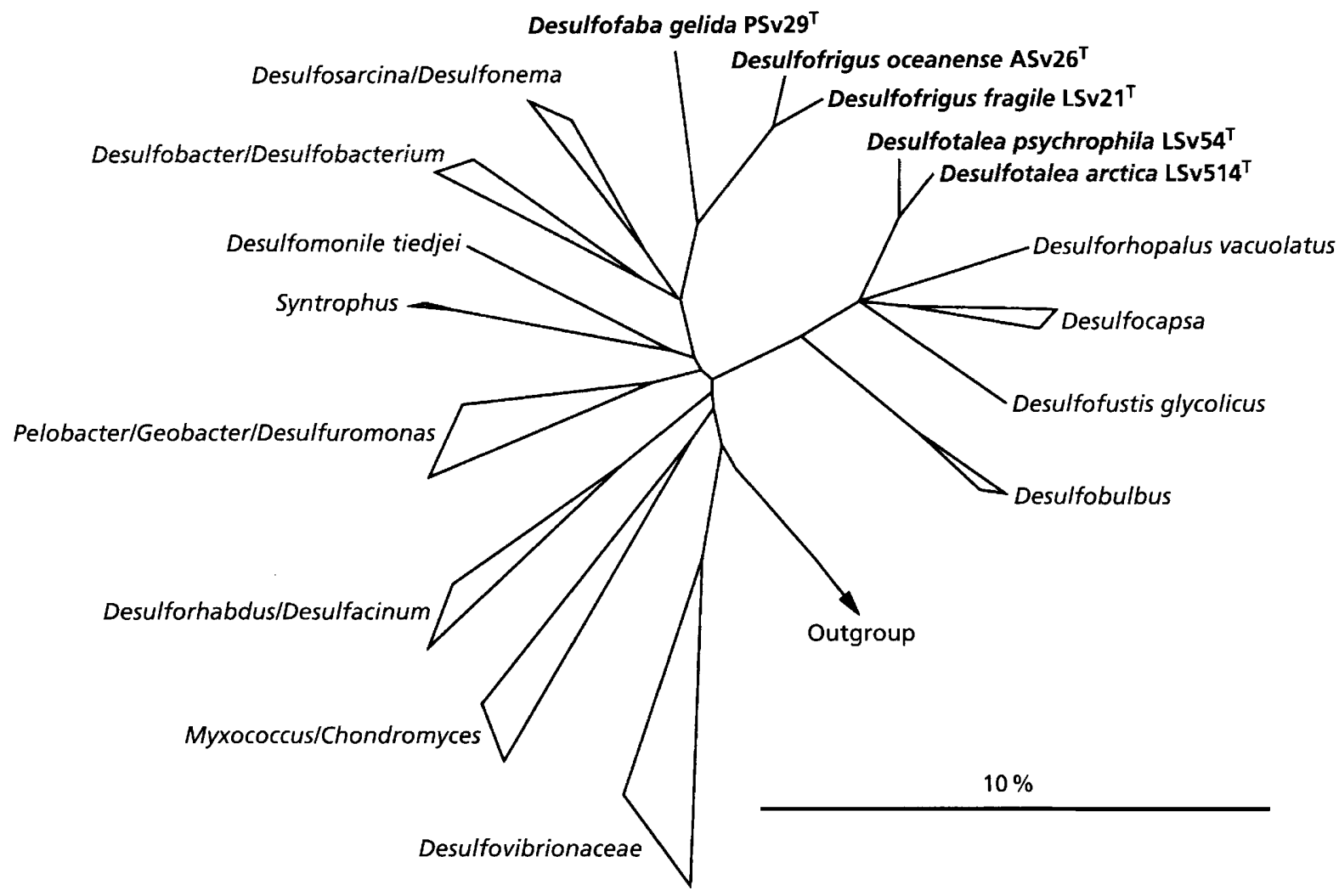

Fig. 2. Distance tree based on 165 rRNA sequences. The tree shows the $\delta$ subclass of Proteobacteria and was constructed by the neighbour-joining method using a $50 \%$ conservation filter. It depicts the phylogenetic distances using Jukes-Cantor correction with the bar representing $10 \%$ estimated sequence divergence. Areas of interest where the branching order changed when different treeing methods were applied are shown as multifurcations. The arrow indicates the position of the outgroup (a selection of bacterial 165 rDNA sequences from a wide range of phyla). In addition to the Svalbard isolates, which are shown here in bold, 37 known species from the $\delta$ subclass of Proteobacteria were selected to reconstruct the tree. These reference species are shown here as groups for a better overview.

the carbon source of PSv29 $9^{\mathrm{T}}$. The second most abundant fatty acid, 15:1c9, is uncommon in sulfatereducing bacteria and was until now found only in low amounts in a Desulfobacter spp. grown on a mixture of fatty acids (Dowling et al., 1986). In strain PSv29 $80 \%$ of the identified fatty acids were odd-numbered, an indication that propionyl-CoA was precursor for chain elongation. The same result was also found in different Desulfobulbus species (Taylor \& Parkes, 1983). Two fatty acids with an ECL of $14.80(5.5 \%)$ and $19.47(7.4 \%)$ could not be identified. Strains LSv $54^{\mathrm{T}}$ and LSv $514^{\mathrm{T}}$ exhibited very similar fatty acid patterns which were clearly different from those of the other new strains. The dominant fatty acids were the monounsaturated $16: 1 c 9$ and $16: 1 c 11$ comprising more than $80 \%$ of the total identified fatty acids. As in ASv $26^{\mathrm{T}}$ and LSv $21^{\mathrm{T}}$, the strains have preferentially even chain fatty acids. Desulforhopalus vacuolatus strain $1 \mathrm{tk} 10^{\mathrm{T}}$ was included in our study since it is, as yet, the only known moderately psychrophilic sulfatereducing bacterium. It is most closely related to strains $\mathrm{LSv} 54^{\mathrm{T}}$ and LSv $514^{\mathrm{T}}$. The fatty acid pattern of Desulforhopalus vacuolatus was clearly dominated by the 17:1c11 fatty acid. Although Desulforhopalus vacuolatus was grown on lactate, propionyl-CoA was used as precursor for chain elongation, since oddnumbered fatty acids dominated, being $87 \%$ of the identified acids.

\section{$\mathrm{G}+\mathrm{C}$ content of genomic DNA}

The $\mathrm{G}+\mathrm{C}$ contents of strains ASv2 $6^{\mathrm{T}}$, LSv $21^{\mathrm{T}}$ and PSv2 $9^{\mathrm{T}}$ were very similar, $52-53 \mathrm{~mol} \%$ (Table 1 ). Lower $\mathrm{G}+\mathrm{C}$ contents were found in LSv $54^{\mathrm{T}}$ $(47 \mathrm{~mol} \%)$ and LSv514 $(42 \mathrm{~mol} \%)$.

\section{Phylogenetic affiliation}

The 16S rDNA sequences showed that all isolates belonged to the $\delta$ subclass of Proteobacteria. Although they share a common characteristic in being psychrophilic, they do not form a cluster within the $\delta$ subclass but are distributed between groups of mesophilic sulfate-reducing bacteria (Fig. 2). All isolates had at least $9 \%$ evolutionary distance from $16 \mathrm{~S}$ rDNA sequences of known mesophilic sulfate-reducing bacteria. Based on their 16S rDNA sequence, strains ASv $26^{\mathrm{T}}$ and LSv $21^{\mathrm{T}}$ are closely related to each other with an evolutionary distance of $3 \cdot 2 \%$. We regard 
them as different species since they showed distinct physiological differences with different substrate spectra and $\mathrm{ASv} 26^{\mathrm{T}}$ is a complete oxidizer whereas $\mathrm{LSv} 21^{\mathrm{T}}$ is an incomplete oxidizer. The closest relative to both strains was PSv29 $9^{\mathrm{T}}$ with evolutionary distances of 10.4 and $10.5 \%$, respectively, followed by Desulfosarcina variabilis with a distance of $11.6 \%$ to ASv $26^{\mathrm{T}}$ and $12 \cdot 2 \%$ to $\mathrm{LSv} 21^{\mathrm{T}}$. PSv $29^{\mathrm{T}}$ was not closely related to any known strain but shares the highest $16 \mathrm{~S}$ rDNA similarity with Desulfosarcina variabilis $(9.5 \%$ evolutionary distance). Strains LSv $54^{\mathrm{T}}$ and LSv $514^{\mathrm{T}}$ were closely related having $3.3 \%$ evolutionary distance. Since their physiological and chemotaxonomic properties were quite similar (Table 1), we performed DNADNA hybridization to establish whether they belonged to the same species. The relative binding ratio for DNA-DNA hybridization of these two isolates was below $20 \%$, which is well below the threshold value of $70 \%$ accepted for the distinction of different species (Wayne et al., 1987). Based on these results, strains LSv54 ${ }^{\mathrm{T}}$ and LSv514 ${ }^{\mathrm{T}}$ can be regarded as two different species. The closest relatives of both strains were Desulfofustis glycolicus and Desulforhopalus vacuolatus with an evolutionary distance of $9 \cdot 0-9 \cdot 3 \%$.

\section{DISCUSSION}

\section{Ecology}

The psychrophilic isolates from permanently cold Arctic sediments are the first known sulfate reducers that are able to grow below $0{ }^{\circ} \mathrm{C}$. The existence of lowtemperature-adapted sulfate reducers was evident, since previous studies demonstrated that rates of sulfate reduction in polar sediments were comparable to those in temperate environments (Nedwell et al., 1993; Sagemann et al., 1998). The new strains LSv54 and LSv514 ${ }^{\mathrm{T}}$ grew fastest on lactate, pyruvate, alcohols and hydrogen, which are the characteristic carbon and energy substrates of Desulfovibrio species. In the present study, no organisms morphologically resembling Desulfovibrio strains were detected in any enrichment incubated between 0 and $10{ }^{\circ} \mathrm{C}$ and no Desulfovibrio strain was isolated at low temperatures. These results are unusual, since Desulfovibrio strains are generally dominant in lactate-containing enrichment cultures (Postgate, 1984). The major difference between previous enrichments and ours was the temperature used for incubation, $28-36{ }^{\circ} \mathrm{C}$ vs $0-10{ }^{\circ} \mathrm{C}$, indicating that growth temperature might affect the outcome of competition between different groups of sulfate reducers. This was also supported by the results of Isaksen \& Teske (1996) who enriched sulfate reducers with lactate from a temperate estuary at $10^{\circ} \mathrm{C}$. They isolated the moderate psychrophilic strain $1 \mathrm{tk} 10^{\mathrm{T}}$, which they described as the type strain of a new genus Desulforhopalus vacuolatus. However, it might also be that Desulfovibrio species are not abundant in the investigated habitat and that their ecological niche is taken by species related to LSv $54^{\mathrm{T}}$ and LSv $514^{\mathrm{T}}$. Strains LSv $21^{\mathrm{T}}$ and PSv2 $9^{\mathrm{T}}$ oxidize various fatty acids such as propionate, butyrate, caproate, caprate and even palmitate incompletely to acetate which can be further oxidized by strain ASv26 ${ }^{\mathrm{T}}$ to $\mathrm{CO}_{2}$. Besides lactate and hydrogen, volatile fatty acids are the most important end-products of fermentation and are the major organic substrates for sulfate reducers in temperate environments (Sørensen et al., 1981; Christensen, 1984; Parkes et al., 1989). The fact that all these compounds were also oxidized at subzero temperatures by the new psychrophilic isolates is a further indication that these bacteria occupy the same ecological niche in cold sediments as the mesophiles in temperate sediments.

\section{Chemotaxonomy}

According to their cellular fatty acid pattern, the new strains can be assigned to three distinct groups. The major fatty acids of both ASv26 $6^{\mathrm{T}}$ and LSv2 $1^{\mathrm{T}}$ were 16:1c9, 18:1c11 and 16:0 acids (Table 2). This combination is unique among the known sulfate reducers and supports the assignment of these two isolates to a new genus. PSv29 ${ }^{\mathrm{T}}$, the closest relative to ASv $26^{\mathrm{T}}$ and $\mathrm{LSv} 21^{\mathrm{T}}$, had a completely different pattern with the 15:0 and the 15:1c9 fatty acids dominating. Both fatty acids were absent in Desulfosarcina variabilis (Kohring et al., 1994), which is phylogenetically the closest related strain to PSv29 $9^{T}$. The third group comprised strains LSv54 ${ }^{\mathrm{T}}$ and LSv $514^{\mathrm{T}}$. Both have a very similar fatty acid pattern dominated by $16: 1 c 9$ and $16: 1 c 11$, a combination which, to our knowledge, has not been found in any other sulfate reducer. Desulforhopalus vacuolatus strain $1 \mathrm{tk} 10^{\mathrm{T}}$ was included in our study since it is moderately psychrophilic and most closely related to strains LSv $54^{\mathrm{T}}$ and LSv $514^{\mathrm{T}}$. Its fatty acid pattern was dominated by 17:1c11 acid (Table 2) but it also contained 15:1c9 acid $(12 \%)$. Therefore, in the Euclidian distance tree (data not shown), ltk $10^{\mathrm{T}}$ was more closely related to PSv29 $9^{\mathrm{T}}$ than to LSv54 ${ }^{\mathrm{T}}$ and LSv514 ${ }^{\mathrm{T}}$. These results cannot be due to differences in the growth conditions, because $1 \mathrm{tk} 10^{\mathrm{T}}, \mathrm{LSv} 54^{\mathrm{T}}$ and $\mathrm{LSv} 514^{\mathrm{T}}$ were all cultivated with lactate on the same medium at $4{ }^{\circ} \mathrm{C}$. The percentage of unsaturated fatty acids in strains LSv $54^{\mathrm{T}}$ and LSv $514^{\mathrm{T}}$ (89 and $91 \%$, respectively; Table 2 ) is remarkably high. Among the mesophilic sulfate-reducing bacteria, the highest content of unsaturated fatty acids was $62 \%$ in Desulfovibrio africanus (Vainshtein et al., 1992). The high degree of unsaturated fatty acids in the new strains may be an adaptation to low temperature. Unsaturated fatty acids lower the gel-liquid-crystalline phase transition temperature of membranes (Russell, 1990), thereby maintaining the necessary fluidity at low growth temperatures. High concentrations of unsaturated fatty acids were also found in $\mathrm{ASv} 26^{\mathrm{T}}$ and $\mathrm{LSv} 21^{\mathrm{T}}$ (Table 2) but not in PSv29 ${ }^{\mathrm{T}}$. Another way to increase membrane fluidity is to decrease the fatty acyl chain length (Bhakoo \& Herbert, 1979). This is the case in PSv29 ${ }^{\mathrm{T}}$, which contains more than $70 \%$ fatty acids with a chain length of 15 carbon atoms or less. It is 
not known if sulfate-reducing bacteria alter their membrane composition when grown at different temperatures.

The MK analyses revealed similar relationships between the new isolates as the fatty acid profiles. ASv $26^{\mathrm{T}}$ and LSv $21^{\mathrm{T}}$ contained only MK-9, which was not found in any of the other new isolates and, out of 45 sulfate-reducing bacteria strains investigated by Collins \& Widdel (1986), it only occurred in Desulfonema magnum. The sole MK in $\mathrm{PSv}^{2} 9^{\mathrm{T}}$ was MK-8, which is absent in its closest relative, Desulfosarcina variabilis (Collins \& Widdel, 1986). MK with six isoprenoid subunits were dominant in strains LSv54 ${ }^{\mathrm{T}}$ and LSv514 ${ }^{\mathrm{T}}$ (Table 1). These MK are characteristic for most Desulfovibrio strains (Collins \& Widdel, 1986). Unfortunately, MK data are not available for their closest relatives, Desulfofustis glycolicus and Desulforhopalus vacuolatus. The chemotaxonomic data were in good agreement with the 16S rRNA sequence data, which showed the same affiliation between the different isolates (Fig. 2). More conflicting results arose from the substrate spectra of strains ASv $26^{\mathrm{T}}$ and $\mathrm{LSv} 21^{\mathrm{T}}$. Although most closely related to ASv26 (evolutionary distance $3 \cdot 2 \%$ ), strain LSv $21^{\mathrm{T}}$ only incompletely oxidized fatty acids to acetate. Complete or incomplete substrate oxidation was traditionally used as a criterion to distinguish genera of sulfate-reducing bacteria (Devereux et al., 1989; Holt et al., 1994). These distinctions have been supported by phylogenetic data. The lowest evolutionary distance between a completely oxidizing species (Desulfococcus multivorans) and an incompletely oxidizing sulfate-reducing bacteria (Desulfovibrio sapovorans) was $11 \%$. Our results demonstrate that complete substrate oxidation to $\mathrm{CO}_{2}$ is not always, phylogenetically, a deep branching property. Chemotaxonomic parameters such as fatty acid pattern and MK content of the different isolates were in closer agreement with the phylogenetic data than the substrate spectra.

Strains LSv $54^{\mathrm{T}}$ and LSv $514^{\mathrm{T}}$ were phylogenetically most closely related to Desulfofustis glycolicus and Desulforhopalus vacuolatus. The new strains shared only a few general characteristics with the genus Desulfofustis, e.g. the absence of desulfoviridin and the incomplete oxidation of lactate. The most conspicuous feature, which the new strains shared with Desulforhopalus vacuolatus, is psychrophily. On the other hand, the new strains could be easily differentiated from Desulforhopalus vacuolatus by the absence of gas vacuoles, by their inability to grow on propionate and by their completely different cellular fatty acid pattern.

\section{Taxonomic affiliation}

Phylogenetically, the closest relative to ASv26 ${ }^{\mathrm{T}}$ and LSv $21^{\mathrm{T}}$ was PSv $29^{\mathrm{T}}$ with evolutionary distances of 10.4 and $10.5 \%$, respectively. Due to this phylogenetic distance, as well as dissimilarities in physiology, the fatty acid pattern and MK content, we propose the establishment of a new genus, Desulfofrigus, for ASv $26^{\mathrm{T}}$ and $\mathrm{LSv} 21^{\mathrm{T}}$. On the basis of an evolutionary distance of $3.2 \%$, distinct morphologies, temperature responses of growth and substrate spectra, we classify ASv26 ${ }^{\mathrm{T}}$ and LSv21 $1^{\mathrm{T}}$ as two species of the genus Desulfofrigus. ASv $26^{\mathrm{T}}$ is the type strain of the type species Desulfofrigus oceanense and $\mathrm{LSv} 21^{\mathrm{T}}$ is the type strain of Desulfofrigus fragile.

Due to the evolutionary distance of $9.5 \%$ between PSv29 ${ }^{\mathrm{T}}$ and Desulfosarcina variabilis and the differences in their physiology and chemotaxonomic properties, we propose the establishment of the new genus Desulfofaba with PSv29 ${ }^{\mathrm{T}}$ as the type strain of the type species Desulfofaba gelida.

Considering the phylogenetic distance between strains

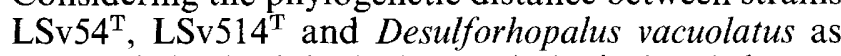
well as their physiological, morphological and chemotaxonomic differences, we place strain $\mathrm{LSv} 54^{\mathrm{T}}$ and LSv $514^{\mathrm{T}}$ in a new genus Desulfotalea. Since both strains have distinct physiological properties and a DNA-DNA similarity of less than $70 \%$, we have defined two new species of the genus Desulfotalea, with $\mathrm{LSv} 54^{\mathrm{T}}$ as the type strain of the type species Desulfotalea psychrophila and LSv514 ${ }^{\mathrm{T}}$ as the type strain of Desulfotalea arctica.

\section{Description of Desulfofrigus gen. nov.}

Desulfofrigus (De.sul.fo.fri'gus. L. prefix de off; L. n. sulfur sulfur; L. neut. n. frigus cold; M.L. neut. n. Desulfofrigus sulfate reducer living in the cold).

Members are Gram-negative, obligately anaerobic bacteria and belong to the $\delta$ subclass of Proteobacteria. Sulfate is used as terminal electron acceptor and reduced to sulfide. Iron(III) can also be used as electron acceptor. Fermentative growth on pyruvate or other carbon substrates. Chemoorganotrophic growth on fatty acids and alcohols that are either completely oxidized to $\mathrm{CO}_{2}$ or incompletely to acetate. No chemoautotrophic growth. Major cellular fatty acids are even, mono-unsaturated and unbranched. MK-9 is the dominant menaquinone. The type species of this genus is Desulfofrigus oceanense. A second member of this genus is Desulfofrigus fragile.

\section{Description of Desulfofrigus oceanense gen. nov., sp.} nov.

Desulfofrigus oceanense (o.ce.a.nen'se. L. adj. oceanensis, $-e$ belonging to the ocean).

Cells are $2 \cdot 1 \mu \mathrm{m}$ wide and $4 \cdot 2-6 \cdot 1 \mu \mathrm{m}$ long. The $\mathrm{pH}$ optimum for growth is $7 \cdot 0-7 \cdot 5$. Requires sodium chloride; optimum growth occurs at marine salt concentrations. Temperature optimum for growth is $10{ }^{\circ} \mathrm{C}$ and growth also occurs at $-1.8^{\circ} \mathrm{C}$. Contains the polar lipids phosphatidylethanolamine and phosphatidylglycerol; MK-9 is the sole menaquinone. Major cellular fatty acids are $16: 1 c 9$ and $18: 1 c 11$. The $\mathrm{G}+\mathrm{C}$ 
content is $52.8 \mathrm{~mol} \%$. Sulfate, thiosulfate and sulfite are used as electron acceptors and are reduced to sulfide. Iron(III) serves as an electron acceptor when added as iron(III) citrate. Elemental sulfur, iron(III) oxyhydroxide, nitrate and nitrite are not reduced. Formate, acetate, butyrate, valerate, lactate, pyruvate, malate, ethanol, propanol, butanol, glycerol, glycine and serine serve as carbon substrates. Fatty acids are oxidized completely to $\mathrm{CO}_{2}$. Growth on $\mathrm{H}_{2}$ plus acetate $(2 \mathrm{mM})$ is slow. Fermentative growth on pyruvate, malate and lactate. Vitamins are not required for growth. Desulfoviridin is absent. Elemental sulfur and thiosulfate are not disproportionated. Habitat is permanently cold marine sediments. Type strain is ASv $26^{\mathbf{T}}$ $\left(=\mathrm{DSM} 12341^{\mathrm{T}}\right)$.

\section{Description of Desulfofrigus fragile sp. nov.}

Desulfofrigus fragile (fra'gi.le. L. adj. fragilis, -e referring to the rapid lysis of the type strain in the stationary phase).

Cells are $0.8 \mu \mathrm{m}$ wide and $3 \cdot 2-4 \cdot 2 \mu \mathrm{m}$ long. The $\mathrm{pH}$ optimum for growth is 7.0-7.4. Requires sodium chloride; optimum growth occurs at marine salt concentrations. Temperature optimum for growth is $18^{\circ} \mathrm{C}$ and growth also occurs at $-1.8^{\circ} \mathrm{C}$. Contains the polar lipids phosphatidylethanolamine and phosphatidylglycerol; MK-9 is the sole menaquinone. Major cellular fatty acids are 16:1c9, 16:0 and $18: 1 c 11$. The $\mathrm{G}+\mathrm{C}$ content is $52 \cdot 1 \mathrm{~mol} \%$. Sulfate is used as electron acceptor and is reduced to sulfide. Elemental sulfur, sulfite, thiosulfate, nitrate, nitrite and iron(III) oxyhydroxide are not reduced. Iron(III) serves as electron acceptor when added as iron(III) citrate. Formate, butyrate, caproate, caprate, palmitate, lactate, pyruvate, malate, fumarate, ethanol, propanol, butanol, glycerol, alanine and serine serve as carbon sources and electron donors. Fatty acids are oxidized incompletely to acetate. Fermentative growth on pyruvate and malate. Vitamins are not required for growth. Desulfoviridin is absent. Cells lyse rapidly in the stationary growth phase. Elemental sulfur and thiosulfate are not disproportionated. Habitat is permanently cold marine sediments. Type strain is LSv21 $1^{\mathrm{T}}\left(=\mathrm{DSM} 12345^{\mathrm{T}}\right)$.

\section{Description of Desulfofaba gen. nov.}

Desulfofaba (De.sul.fo.fa'ba. L. prefix de off; L. n. sulfur sulfur; L. fem. n. faba a bean; M.L. fem. n. Desulfofaba a sulfate-reducing bean).

Members are Gram-negative, obligately anaerobic bacteria belonging to the $\delta$ subclass of Proteobacteria. Sulfate is used as electron acceptor and reduced to sulfide. Fermentative growth on pyruvate or other carbon substrates is possible. Major carbon sources and electron donors are fatty acids and alcohols that are oxidized incompletely to acetate. Major cellular fatty acids are odd-numbered and uribranched. MK-8 is the dominant menaquinone. The xype species is the only species in the genus, Desulfofaba gelida.

\section{Description of Desulfofaba gelida gen. nov., sp. nov.}

Desulfofaba gelida (ge'li.da. L. adj. gelidus, - $a$, -um icecold, referring to the low temperature optimum).

Cells are $3.1 \mu \mathrm{m}$ wide and $5.4-6.2 \mu \mathrm{m}$ long. The $\mathrm{pH}$ optimum for growth is $7 \cdot 1-7 \cdot 6$. Requires sodium chloride and magnesium chloride; optimum growth occurs at marine salt concentrations. The temperature optimum for growth is $7^{\circ} \mathrm{C}$; growth also occurs at $-1.8^{\circ} \mathrm{C}$. Contains the polar lipids phosphatidylethanolamine and phosphatidylglycerol; MK- 8 is the sole menaquinone. Major cellular fatty acids are 15:0 and $15: 1 c 9$. The $\mathrm{G}+\mathrm{C}$ content is $52.5 \mathrm{~mol} \%$. Sulfate, thiosulfate and sulfite are used as electron acceptors which are reduced to sulfide. Elemental sulfur, nitrate, nitrite, iron(III) oxyhydroxide and iron(III) citrate are not reduced. Sulfur and thiosulfate are not disproportionated. Formate, propionate, butyrate, lactate, pyruvate, malate, succinate, fumarate, ethanol, propanol, butanol, glycerol, glycine and alanine serve as carbon sources. Fatty acids are oxidized incompletely to acetate. Fermentative growth on pyruvate and fumarate. Vitamins are not required for growth. Desulfoviridin is absent. Their habitat is permanently cold marine sediments. Type strain is PSv $29^{\mathrm{T}}(=\mathrm{DSM}$ $\left.12344^{\mathrm{T}}\right)$.

\section{Description of genus Desulfotalea gen. nov.}

Desulfotalea (De.sul.fo.ta'le.a. L. prefix de off; L. n. sulfur sulfur; L. fem. n. talea a rod; M.L. fem. n. Desulfotalea a sulfate-reducing rod).

Members are Gram-negative obligately anaerobic bacteria belonging to the $\delta$ subclass of Proteobacteria. Sulfate is used as electron acceptor and reduced to sulfide. Fermentative growth on pyruvate. Iron(III) can be used as electron acceptor. Major carbon or energy sources are lactate, alcohols and hydrogen. Cellular fatty acids comprise even-numbered, monounsaturated acids. The dominant menaquinones have six isoprenoid units. Desulfotalea psychrophila is the type species of the genus. A second member of this genus is Desulfotalea arctica.

\section{Description of Desulfotalea psychrophila gen. nov., sp. nov.}

Desulfotalea psychrophila (psy.chro'phi.la. Gr. adj. psychros cold; philos loving; M.L. adj. psychrophilus, - $a$, -um cold-loving).

Cells are $0.6 \mu \mathrm{m}$ wide and $4.5-7.4 \mu \mathrm{m}$ long. The $\mathrm{pH}$ optimum for growth is 7.3-7.6. Requires sodium chloride and magnesium chloride for growth; optimum sodium chloride concentration is $1 \%$. The temperature optimum for growth is $10^{\circ} \mathrm{C}$ and growth also occurs at $-1 \cdot 8^{\circ} \mathrm{C}$. Cells contain the polar lipids phosphatidylethanolamine, phosphatidylglycerol and diphosphatidylglycerol. MK- $6 \mathrm{H}_{2}$ is the major menaquinone but traces of $\mathrm{MK}-5 \mathrm{H}_{2}$ are also present. Major cellular fatty acids are $16: 1 c 9$ and $16: 1 c 11$. The $\mathrm{G}+\mathrm{C}$ 
content is $46.8 \mathrm{~mol} \%$. Sulfate, thiosulfate and sulfite are used as electron acceptors and are reduced to sulfide. Elemental sulfur, nitrate, nitrite and iron(III) oxyhydroxide are not reduced. Growth by reduction of iron(III), if added as iron(III) citrate, is possible. Elemental sulfur or thiosulfate are not disproportionated. Formate, lactate, pyruvate, malate, fumarate, ethanol, propanol, butanol, glycine, alanine and serine serve as carbon sources. They grow on hydrogen plus acetate $(2 \mathrm{mM})$. Organic substrates are oxidized incompletely to acetate. Fermentative growth on pyruvate and fumarate. Vitamins are not required. Desulfoviridin is absent. Habitat is permanently cold marine sediments. Type strain is LSv54 ${ }^{\mathrm{T}}$ (=DSM $\left.12343^{\mathrm{T}}\right)$.

\section{Description of Desulfotalea arctica sp. nov.}

Desulfotalea arctica (arc'ti.ca. L. adj. arcticus, - $a$, -um from the Arctic, referring to the site were the type strain was isolated).

Cells are $0.7 \mu \mathrm{m}$ wide and $1.6-2.7 \mu \mathrm{m}$ long. The $\mathrm{pH}$ optimum for growth is $7 \cdot 2-7 \cdot 9$. Sodium chloride and magnesium chloride are required for growth; optimum growth occurs at marine salt concentrations. The temperature optimum for growth is $18{ }^{\circ} \mathrm{C}$ and growth also occurs at $-1.8^{\circ} \mathrm{C}$. Cells contain the polar lipids phosphatidylethanolamine, phosphatidylglycerol and diphosphatidylglycerol. MK-6 is the sole menaquinone. Major cellular fatty acids are 16:1c9 and $16: 1 c 11$. The $\mathrm{G}+\mathrm{C}$ content is $41.8 \mathrm{~mol} \%$. Sulfate serves as electron acceptor and is reduced to sulfide. Thiosulfate, sulfite, nitrate and nitrite are not reduced. Growth by reduction of iron(III), if added as iron(III) citrate. Elemental sulfur and iron(III) oxyhydroxide are slowly reduced without growth. Elemental sulfur and thiosulfate are not disproportionated. Formate, lactate, pyruvate, ethanol, glycerol and serine serve as carbon sources and electron donors. Hydrogen plus acetate $(2 \mathrm{mM})$ allows rapid growth. Organic substrates are oxidized incompletely to acetate. Fermentative growth on pyruvate. Vitamins are not required for growth. Desulfoviridin is absent. Habitat is permanently cold marine sediments. Type strain is LSv514 ${ }^{\mathrm{T}}$ (= DSM 12342 ${ }^{\mathrm{T}}$ ).

\section{ACKNOWLEDGEMENTS}

We thank Ramon Rosselló-Mora for help with the DNADNA hybridization and helpful discussions on taxonomy, Jens Harder for introduction to anaerobic cultivation techniques, and Jan Küver for helpful hints and for critically reading the manuscript. Friedrich Widdel is thanked for many inspiring discussions. Donald E. Canfield is thanked for leading the cruise to Svalbard and Svantje Fleischer and Birgit Rattunde for technical assistance. This work was financially supported by the Max Planck Society, Germany.

\section{REFERENCES}

Bhakoo, M. \& Herbert, R. A. (1979). The effects of temperature on the fatty acid and phospholipid composition of four obligately psychrophilic Vibrio spp. Arch Microbiol 121, 121-127.
Brosius, J., Dull, T. J., Sleeter, D. D. \& Noller, H. F. (1981). Gene organization and primary structure of a ribosomal RNA operon from Escherichia coli. J Mol Biol 148, 107-127.

Buchholz-Cleven, B. E. E., Rattunde, B. \& Straub, K. L. (1997). Screening for genetic diversity of isolates of anaerobic $\mathrm{Fe}(\mathrm{II})$ oxidizing bacteria using DGGE and whole-cell hybridization. Syst Appl Microbiol 20, 301-309.

Canfield, D. E., Jørgensen, B. B., Fossing, H. \& 7 other authors (1993). Pathways of organic carbon oxidation in three continental margin sediments. Mar Geol 113, 27-40.

Christensen, D. (1984). Determination of substrates oxidized by sulfate reduction in intact cores of marine sediments. Limnol Oceanogr 29, 189-192.

Cline, J. D. (1969). Spectrophotometric determination of hydrogen sulfide in natural waters. Limnol Oceanogr 14, 454-458.

Collins, M. D. \& Widdel, F. (1986). Respiratory quinones of sulphate-reducing and sulphur-reducing bacteria: a systematic investigation. Syst Appl Microbiol 8, 8-18.

Cord-Ruwisch, R. (1985). A quick method for the determination of dissolved and precipitated sulfides in cultures of sulfatereducing bacteria. J Microbiol Methods 4, 33-36.

Cutter, G. A. \& Radford-Knoery, J. (1991). Determination of carbon, nitrogen, sulfur, and inorganic sulfur species in marine particles. In Marine Particles: Analysis and Characterization, pp. 57-63. Edited by D. C. Hurd. Washington, DC: American Geophysical Union.

Devereux, R., Delaney, M., Widdel, F. \& Stahl, D. A. (1989). Natural relationships among sulfate-reducing bacteria. $J$ Bacteriol 171, 6689-6695.

Dowling, N. J. E., Widdel, F. \& White, D. C. (1986). Phospholipid ester-linked fatty acid biomarkers of acetate-oxidizing sulphatereducers and other sulphide-forming bacteria. J Gen Microbiol 132, 1815-1825.

Glud, R. N., Holby, O., Hoffmann, F. \& Canfield, D. E. (1998). Benthic mineralization and exchange in Arctic sediments (Svalbard, Norway). Mar Ecol Prog Ser 173, 237-251.

Holt, J. G., Krieg, N. R., Sneath, P. H. A., Staley, J. T. \& Williams, S. T. (editors) (1994). Bergey's Manual of Determinative Bacteriology. Baltimore: Williams \& Wilkins.

Isaksen, M. F. \& Teske, A. (1996). Desulforhopalus vacuolatus gen. nov., sp. nov., a new moderately psychrophilic sulfate-reducing bacterium with gas vacuoles isolated from a temperate estuary. Arch Microbiol 166, 160-168.

Jørgensen, B. B. (1982). Mineralization of organic matter in the sea bed - the role of sulphate reduction. Nature 296, 643-645.

Knoblauch, C. \& Jørgensen, B. B. (1999). Effect of temperature on sulphate reduction, growth rate, and growth yicld in five psychrophilic sulphate-reducing bacteria from Arctic sediments. Env Microbiol (in press).

Kohring, L. L., Ringelberg, D. B., Devereux, R., Stahl, D. A., Mittelman, M. W. \& White, D. C. (1994). Comparison of phylogenetic relationships based on phospholipid fatty acid profiles and ribosomal RNA sequence similarities among dissimilatory sulfate-reducing bacteria. FEMS Microbiol Lett 119, 303-308.

Levitus, S. \& Boyer, T. (1994). World Ocean Atlas, vol. 4, Temperature. Washington, DC: US Department of Commerce. Lind, E. \& Ursing, J. (1986). Clinical strains of Enterobacter agglomerans (synonyms: Erwinia herbicola, Erwinia milletiae) identified by DNA-DNA hybridization. Acta Pathol Microbiol Immunol Scand Sect B Microbiol 94, 205-213.

Marmur, J. (1961). A procedure for the isolation of deoxy- 
ribonucleic acid from micro-organisms. $J$ Mol Biol 3, 208-218. Mesbah, M., Premachandran, U. \& Whitman, W. B. (1989). Precise measurement of the $\mathrm{G}+\mathrm{C}$ content of deoxyribonucleic acid by high-performance liquid chromatography. Int $J$ Syst Bacteriol 39, 159-167.

Murray, R. G. E., Doetsch, R. N. \& Robinow, C. F. (1994). Determinative and cytological light microscopy. In Methods for General and Molecular Bacteriology, pp. 21-41. Edited by P. Gerhardt, R. G. E. Murray, W. A. Wood \& N. R. Krieg. Washington, DC: American Society for Microbiology.

Nedwell, D. B., Walker, T. R., Ellis-Evans, J. C. \& Clarke, A. (1993). Measurements of seasonal rates and annual budgets of organic carbon fluxes in an Antarctic coastal environment at Signy Island, South Orkney Islands, suggest a broad balance between production and decomposition. Appl Environ Microbiol 59, 3989-3995.

Parkes, R. J., Gibson, G. R., Mueller-Harvey, I., Buckingham, W. J. \& Herbert, R. A. (1989). Determination of the substrates for sulphate-reducing bacteria within marine and estuarine sediments with different rates of sulphate reduction. $J$ Gen Microbiol 135, 175-187.

Postgate, J. R. (1984). The Sulphate-reducing Bacteria. Cambridge: Cambridge University Press.

Rosselló-Mora, R. A., Caccavo, F., Jr, Osterlehner, K. \& 7 other authors (1994). Isolation and taxonomic characterization of a halotolerant, facultatively iron-reducing bacterium. Syst Appl Microbiol 17, 569-573

Russell, N. J. (1990). Cold adaptation of microorganisms. Philos Trans $R$ Soc Lond B Biol Sci 326, 595-611.

Sagemann, J., Jørgensen, B. B. \& Greef, O. (1998). Temperature dependence and rates of sulfate reduction in cold sediments of Svalbard, Arctic Ocean. Geomicrobiol J 15, 85-100.
Sørensen, J., Christensen, D. \& Jørgensen, B. B. (1981). Volatile fatty acids and hydrogen as substrates for sulfate-reducing bacteria in anaerobic marine sediment. Appl Environ Microbiol 42, 5-11.

Stookey, L. L. (1970). Ferrozine - a new spectrophotometric reagent for iron. Anal Chem 42, 779-781.

Strunk, O., Gross, O., Reichel, B. \& 11 other authors (1999). ARB: a software environment for sequence data. http:// www.mikro.biologie.tu-muenchen.de. Department of Microbiology, Technische Universität München, Munich, Germany.

Taylor, J. \& Parkes, R. J. (1983). The cellular fatty acids of the sulphate-reducing bacteria, Desulfobacter sp., Desulfobulbus sp. and Desulfovibrio desulfuricans. J Gen Microbiol 129 , 3303-3309.

Tindall, B. J. (1990). A comparative study of the lipid composition of Halobacterium saccharovorum from various sources. Syst Appl Microbiol 12, 128-130.

Vainshtein, M., Hippe, H. \& Kroppenstedt, R. M. (1992). Cellular fatty acid composition of Desulfovibrio species and its use in classification of sulfate-reducing bacteria. Syst Appl Microbiol 15, 554-566.

Wayne, L. G., Brenner, D. J., Colwell, R. R. \& 9 other authors (1987). International Committee on Systematic Bacteriology. Report of the ad hoc committee on reconciliation of approaches to bacterial systematics. Int $J$ Syst Bacteriol 37, 463-464.

Widdel, F. \& Bak, F. (1992). Gram-negative mesophilic sulfatereducing bacteria. In The Prokaryotes, pp. 3352-3378. Edited by A. Balows, H. G. Trüper, M. Dworkin, W. Harder \& K.-H. Schleifer. New York: Springer.

Ziemke, F., Höfle, M. G., Lalucat, J. \& Rosselló-Mora, R. (1998). Reclassification of Shewanella putrefaciens Owen's genomic group II as Shewanella baltica sp. nov. Int $J$ Syst Bacteriol 48, 179-186. 